\title{
Supplementary Value of Vegetable-milk Curds in the Diet of Children
}

\author{
BY V. SUBRAHMANYAN, SARANYA KUMARI REDDY, \\ M. N. MOORJANI, GOWRI SUR, T. R. DORAISWAMY,
} A. N. SANKARAN, D. S. BHATIA AND M. SWAMINATHAN

Central Food Technological Research Institute, Mysore, India

(Received ro April 1954)

One of the most important food problems of India and the Far East in general is the provision of adequate amounts of milk and other dairy products in the diet of the people. The per caput daily consumption of milk in India has been estimated at 5.4 oz. (Agricultural Marketing Adviser to the Government of India, 1950), which is inadequate as compared with the recommended minimum requirement of ro oz. (Indian Council of Medical Research: Nutrition Advisory Committee, 1944). With the prospects of further increase in population, the milk shortage is likely to become very acute.

With a view to making up the shortage in the essential constituents, especially protein, minerals and vitamins, various attempts have been made in India to prepare palatable and adequately fortified milk substitutes from soya bean, groundnut and other raw materials (De \& Subrahmanyan, 1945; Desikachar \& Subrahmanyan, 1949; Nandi, Rajagopalan \& De, I953). More recently a method for large-scale production of an improved type of vegetable milk has been standardized by Subrahmanyan, Moorjani \& Bhatia (1952). Metabolic studies with albino rats have shown that the calcium in such a milk is well utilized (Moorjani \& Subrahmanyan, 195०a) and that the calcium-fortified milk possesses a marked supplementary value to the poor rice diet (Moorjani \& Subrahmanyan, 1950b).

Extensive consumer trials carried out by us (unpublished) in several parts of India have shown that the lactic-fermented curd and buttermilk prepared from the vegetable milk are highly acceptable and, for practical purposes, indistinguishable from similar products made out of cow's or buffalo's milk. Feeding experiments conducted by us (unpublished) on thousands of children in different areas in Mysore and Madras States have further confirmed that the curd is easily assimilable and forms a good supplement providing about $25^{\circ} \mathrm{mg}$ calcium daily at an intake of $8 \mathrm{oz}$. curd. As further quantitative data are needed, a programme of feeding experiments with children was undertaken in a local boarding home to study the supplementary value of vegetable-milk curd to the diet.

\section{EXPERIMENTAL}

\section{Preparation of the vegetable-milk curd}

Good quality, mature groundnut (Arachis hypogea Linn.) kernels were mildly roasted to remove the testa. The kernels were then ground to a fine paste in a roller mill or other suitable grinding machine. The fine paste, thus obtained, was efficiently mixed 
with a quantity of water and filtered and its $\mathrm{pH}$ was adjusted to 6.8-7. The milk was then deodorized with steam, cooled, fortified with minerals and vitamins and homogenized. To the prepared milk, invert sugar in solution $\left(55^{\circ} \mathrm{Brix}\right)$ to correspond to $\mathrm{I} \%$ was added and the milk was seeded with buttermilk prepared from cow's milk curd. The seed corresponded to $\mathrm{I} \%$ of the vegetable milk. After $\mathrm{I} 2 \mathrm{~h}$ at room temperature $\left(26-28^{\circ}\right)$, the curd set to a thick mass indistinguishable from that of the cow's milk product. Conversion of milk into curds does not bring about any appreciable change in the chemical composition (Moorjani \& Bhatia, 1953, I954). The composition of the curd as compared with that of the cow's milk product is given in Table $x$.

Table I. The chemical composition of vegetable-milk curd from groundnuts compared with that of cow's milk curd

$\begin{array}{lcc} & \begin{array}{c}\text { Vegetable-milk } \\ \text { curd }\end{array} & \begin{array}{c}\text { Cow's milk } \\ \text { curd }\end{array} \\ \text { Protein }(\mathrm{N} \times 6.25)(\%) & 3.00 & 3.30 \\ \text { Fat }(\%) & 5.20 & 3.75 \\ \text { Carbohydrate (\%) } & 3.07 & 4.85 \\ \text { Ash (\%) } & 0.80 & 0.72 \\ \text { Total solids (\%) } & 12.07 & 12.62 \\ \text { Ca (mg/roo g) } & 110 & 110 \\ \text { P (mg/100 g) } & 102 & 70 \\ \text { Fe } & 1.47(\mathrm{mg} / 100 \mathrm{~g}) & 0.2-0.5 \mathrm{p} . \mathrm{p} . \mathrm{m} \text {. } \\ & 0.65 & \\ \text { Thiamine (mg) } & 2.00 & 0.45 \\ \text { Riboflavin (mg) } & 11 \cdot 10 & 1 \cdot 70 \\ \text { Nicotinic acid (mg) } & 17.7 & 1.26 \\ \text { Ascorbic acid (mg) } & 1400 & 15.9 \\ \text { Vitamin A (i.u.) } & 200 & 1320 \\ \text { Vitamin D (i.u.) } & & 20\end{array}$

\section{Subjects}

Selection. A boarding home containing roo girls of ages ranging from 4 to 15 years was chosen for the investigation. All the girls below 12 years were clinically examined. Forty-two girls aged between 4 and I I years and free from diseases likely to interfere with the experiment were selected as experimental subjects. All the girls were treated for worms by the administration of santonin 2 weeks before the beginning of the experiment.

\section{Physical measurements and assessment of nutritional status}

Height, weight, nutritional-deficiency score, R.B.C. and haemoglobin were determined according to the methods described in an earlier paper (Reddy, Doraiswamy, Sankaran, Swaminathan \& Subrahmanyan, 1954). Height was recorded to the nearest $\frac{1}{8}$ in. and weight to the nearest $\frac{1}{8} \mathrm{lb}$. On the basis of the initial height, weight, and nutritional status, the children were paired and the members of each pair were allotted at random to two groups of twenty-one.

\section{Composition of experimental diets and feeding of children}

A diet survey was conducted in the same manner as described in an earlier paper (Reddy et al. 1954). The pattern of the diets consumed by the two groups is given in Table 2. The nutritive value of the diets calculated using the figures given by 
Aykroyd, Patwardhan \& Ranganathan (I95I), together with the dietary requirements for children of similar age group suggested by the Indian Council of Medical Research: Nutrition Advisory Committee (1944) are given in Table 3. The subjects were fed three times a day. The pattern of breakfast, lunch and dinner was similar to that described in a previous paper (Reddy et al. 1954). In addition to the diet each subject in the experimental group was given daily a supplement

Table 2. Diets consumed daily by the children under experiment

Foodstuff

Daily intake/child

(oz.)

Basal (common to both groups):

Raw rice

Ragi (Eleusine coracana)

Wheat

Pulses (red gram (Cajanus indicus) and horse gram (Dolichos biflorus))

Oil (groundnut)

Jaggery (crude cane-sugar)

Common salt

Tamarind (Tamarindus indicus) pulp from the fruit

Condiments (chillies, garlic and fenugreek)

Vegetables (pumpkin, radish, brinjals, radish tops)

Onions

Meat

Milk

Supplement:

Control group:

Corn starch

Cane sugar

Experimental group:

Vegetable-milk curd
$7 \cdot 18$

$I \cdot 4^{\circ}$

0.28

0.73

0.09

0.56

0.26

0.07

0.14

$1 \cdot 55$

0.07

0.14

0.35

I*2

$\mathbf{I} \cdot \mathbf{I}$

$12 \cdot 0$

The average consumption unit for both the groups was 0.8 and was calculated using the international scale of family coefficients (League of Nations Health Organization, 1932).

Table 3. Average daily intake of different nutrients by the children under experiment

\begin{tabular}{lccc}
\multicolumn{1}{c}{ Nutrient } & Control group & $\begin{array}{c}\text { Vegetable-milk } \\
\text { curd group }\end{array}$ & $\begin{array}{c}\text { N.A.C. } \\
\text { standard* }\end{array}$ \\
Calories (Cal.) & I3I I & 1311 & 2000 \\
Protein (g) & 25.2 & 35.4 & 57 \\
Carbohydrate (g) & 281.4 & 231.8 & - \\
Fat (g) & 9.1 & 26.8 & - \\
Calcium (g) & 0.332 & 0.706 & $1-1 \cdot 50$ \\
Phosphorus (g) & 0.712 & 1.052 & - \\
Iron (mg) & 18.4 & 19.8 & $10-30$ \\
Vitamin A: & & & $3000-4000$ \\
As vitamin A (i.u.) & 19.0 & 495 & - \\
As carotene (i.u.) & 781 & 781 & $0.5-1 \cdot 0$ \\
Thiamine (mg) & 0.705 & 0.926 & $12 \dagger$ \\
Nicotinic acid (mg) & 6.8 & 10.6 & $1.8 \dagger$ \\
Riboflavin (mg) & 0.236 & 0.916 & $30-40$ \\
Ascorbic acid (mg) & 21.6 & 27.6 & $400-500$ \\
Vitamin D (i.u.) & - & 68 &
\end{tabular}

- Recommendations of the Indian Council of Medical Research: Nutrition Advisory Committee (1944).

+ Recommendations of the (U.S.A.) National Research Council: Food and Nutrition Board (1948). 
of $12 \mathrm{oz}$. of vegetable-milk curd. In order to equalize the caloric intake in the two groups, each subject in the control group was given daily corn-starch and sugar pudding prepared from $\mathbf{I} \cdot 2 \mathrm{oz}$. of corn starch and $\mathrm{I} \cdot \mathrm{I}$ oz. sugar. The supplements were consumed in three portions along with breakfast, lunch and dinner. All the children relished the supplements. None complained of any digestive trouble during the experimental period. The experiment was begun in June $195^{2}$ and lasted for a period of 6 months, at the end of which the height, weight, nutritional status, R.B.C. and haemoglobin were again determined.

\section{RESUL'TS}

Table 4 shows the initial and final values of the different measurements. It will be seen that at the commencement of the experiment the two groups of subjects were closely similar. For the purpose of statistical analysis the increase in the various measurements during the experimental period was obtained for each subject: from

Table 4. Average values for the initial and final measurements in the control and experimental groups (twenty-one girls in each group)

\begin{tabular}{|c|c|c|c|c|c|c|c|}
\hline \multirow[b]{2}{*}{ Character } & \multicolumn{3}{|c|}{ Control group (a) } & \multicolumn{3}{|c|}{ Experimental group (b) } & \multirow{2}{*}{$\begin{array}{c}\text { Difference in } \\
\text { increase } \\
(b-a)\end{array}$} \\
\hline & Initial & Final & Increase & Initial & Final & Increase & \\
\hline Height (in.) & $46 \cdot 30$ & $46 \cdot 93$ & 0.63 & $46 \cdot 06$ & $47 \cdot 02$ & 0.96 & $0.33 \pm 0.10^{* *}$ \\
\hline Weight (lb.) & $41 \cdot 98$ & $43 \cdot 26$ & $1 \cdot 28$ & $42 \cdot 71$ & $45 \cdot 27$ & $2 \cdot 56$ & $1 \cdot 28 \pm 0.42 * *$ \\
\hline $\begin{array}{l}\text { Haemoglobin }(\mathrm{g} / 100 \mathrm{ml} \text {. } \\
\text { blood) }\end{array}$ & I I $\cdot 20$ & $11 \cdot 37$ & 0.17 & 1157 & $11 \cdot 78$ & $0.2 x$ & $0.04 \pm 0.26$ \\
\hline $\begin{array}{l}\text { Red blood cell count } \\
\left(10^{6} / \mathrm{cu} . \mathrm{mm}\right)\end{array}$ & $4 \cdot 13$ & $4 \cdot 38$ & 0.25 & $4 \cdot 25$ & 4.53 & $0 \cdot 28$ & $0.03 \pm 0.12$ \\
\hline $\begin{array}{l}\text { Nutritional-deficiency } \\
\text { score }\end{array}$ & 5.09 & 6.57 & $r \cdot 48$ & $5 \cdot 29$ & $5 \cdot 14$ & -0.15 & $-1.63 \pm 0.50^{* *}$ \\
\hline
\end{tabular}

these measurements the average increase was obtained for each group. The differences in the average increase between the two groups were tested by the $t$ test appropriate for paired comparisons. The results for the statistical analysis are also presented in Table 4. It will be seen that the increase in height in the experimental group was larger than that in the control group, the difference being highly significant $(P<0.01)$. Similarly the average gain in weight in the experimental group was double that in the control group, the difference being highly significant $(P<0.01)$. Although there was appreciable deterioration in the nutritional status of the children in the control group, there was some improvement in the experimental group, the difference in the change in the nutritional-deficiency score between the two groups being highly significant $(P<0.01)$.

\section{SUMMARY}

I. A feeding experiment extending over a period of 6 months was carried out on forty-two girls aged between 4 and I I years in a boarding home in Mysore to assess the value of adding a supplement of vegetable-milk curd to the diet.

2. Data regarding the weight, height, nutritional status, haemoglobin level and R.B.c. count were obtained at the beginning and the end of the experiment for children in the control and in the experimental groups. 
3. The results of statistical analysis showed a significant improvement in the weight, height and nutritional status of children receiving the supplement of vegetable-milk curd over those in the control group.

We are obliged to the authorities of the Good Shepherd Convent in Mysore for providing us with all facilities for conducting this experiment.

\section{REFERENCES}

Agricultural Marketing Adviser to the Government of India (1950). Report on the Marketing of Milk in the Indian Union. Agric. Mktg India, Ser. no. 64, p. 43. Delhi: Manager of Publications.

Aykroyd, W. R., Patwardhan, V. N. \& Ranganathan, S. (195I). The Nutritive Value of Indian Foods and the Planning of Satisfactory Diets, 4 th ed. Delhi: Manager of Publications.

De, S. S. \& Subrahmanyan, V. (1945). Curr. Sci. 14, 204.

Desikachar, H. S. R. \& Subrahmanyan, V. (r949). Indian Y. med. Res. 37, 77.

Indian Council of Medical Research: Nutrition Advisory Committee (1944). Report of the Scientific Advisory Board for the Year 1944. Delhi: Indian Council of Medical Research.

League of Nations Health Organization (1932). Quart. Bull. Hlth Org. L.O.N. 1, 479.

Moorjani, M. N. \& Subrahmanyan, V. (1950a). Indian Y. med. Res. 38, 59.

Moorjani, M. N. \& Subrahmanyan, V. (1950b). Indian $\mathcal{~}$. med. Res. 38, 139.

Moorjani, M. N. \& Bhatia, D. S. (1953). Bull. cent. Fd tech. Res. Inst. 2, 101.

Moorjani, M. N. \& Bhatia, D. S. (1954). F. sci. industr. Res. (In the Press.)

Nandi, D. K., Rajagopalan, R. \& De, S. S. (1953). Indian Y. Physiol. Allied Sci. 7, I.

National Research Council: Food and Nutrition Board (1948). Repr. nat. Res. Coun., Wash., no. 127.

Reddy, S. K., Doraiswamy, T. R., Sankaran, A. N., Swaminathan, M. \& Subrahmanyan, V. (I954). Brit. Y. Nutr. 8, 17.

Subrahmanyan, V., Moorjani, M. N. \& Bhatia, D. S. (1952). Indian Patent no. 47902. 